Original research article

\title{
The effect of educational intervention based on the health belief model on the promotion of cardiovascular disease (CVD) preventive behaviors among subjects referred to health centers in Fasa city (Fars province, Iran)
}

\author{
Mohammadreza Kheiri ${ }^{1}$, Ali Khani Jeihooni ${ }^{1 *}$, Abdulhakim Alkamel ${ }^{2}$, Pooyan Afzali Harsini ${ }^{3}$ \\ ${ }^{1}$ Fasa University of Medical Sciences, Faculty of Health, Department of Public Health, Fasa, Iran \\ ${ }^{2}$ Fasa University of Medical Sciences, Faculty of Medicine, Department of Cardiovascular Disease, Fasa, Iran \\ ${ }^{3}$ Kermanshah University of Medical Sciences, Faculty of Public Health, Department of Public Health, Kermanshah, Iran
}

\begin{abstract}
Aim: Cardiovascular disease (CVD), as a non-communicable disease, is one of the major causes of death in different countries and imposes a huge health, social and economic burden on society. This study aimed to determine the effect of educational intervention based on the health belief model on the promotion of CVD preventive behaviors among subjects referred to health centers in Fasa city, Fars province, Iran.

Methods: This study is a quasi-experimental study with 200 subjects (100 experimental group and 100 control group) referred to Fasa health centers in 2017-2018. Data were collected using a self-created questionnaire including demographic variables, awareness, HBM constructs and preventive behaviors. It was completed by both groups before the intervention and 3 months after it. Training sessions included 8 sessions held during two months (one session per week) and each session lasted 55-60 minutes. Then, the data were entered into the SPSS 19 and were analyzed using Chi-square test, independent $t$-test, and descriptive statistical methods. $P<0.05$ was considered as statistically significant.

Results: The age of participants was $50.28 \pm 4.76$ years in the experimental group and $49.85 \pm 4.94$ years in the control group ( $p=$ 0.265). The mean BMI was $25.13 \pm 2.18$ in the experimental group and $24.86 \pm 2.40(p=0.316)$ in the control group. The mean scores of HBM Model constructs and Performance were significantly increased in the experimental group compared to the controls after the intervention $(P<0.05)$.

Conclusions: Results showed the effectiveness of the intervention program and the need to use educational interventions designed to improve the adoption of CVD preventive behaviors.
\end{abstract}

Keywords: Cardiovascular Disease; Educational Intervention; Health Belief Model

\section{Introduction}

Non-communicable diseases are on the rise in many countries, mainly due to increased longevity, increased and prolonged exposure to risk factors and changes in lifestyles (Murray et al., 1996).

Cardiovascular disease (CVD), as a chronic, non-communicable disease, is one of the major causes of death in different countries (Hosseini-Esfahani et al., 2011). The number of people suffering from CVD is set to rise over the coming years (Heidenreich et al., 2011; Mathers and Loncar, 2006; Moran et al., 2010). This increasing trend is not limited to low and middle-income countries. Even in high-income countries, the leading cause of disease burden is attributed to CVD (Gaziano et al., 2010; Mathers and Loncar, 2006).
In 2016, non-communicable diseases (NCDs) killed 287,000 people in Iran. Ascending trends of the number of related death and disability-adjusted life years (DALYs) during the past decades show the terrific threat for Iran. NCDs not only result in premature death but also lead to considerable disability (GBD 2016 Causes of Death Collaborators, 2017; GBD 2016 Disease and Injury Incidence and Prevalence Collaborators, 2017). The occurrence of 6.5 million years of life lost (YLLs), and 8.2 million years of living with disability (YLDs) is a dramatic signal of emerging NCDs (Institute for Health Metrics and Evaluation, 2018). Therefore, Iran, just like other countries, is responsible for preventing and controlling NCDs and responding to the call of WHO for a $25 \%$ reduction by 2025 in premature mortality from non-communicable diseases (Peykari et al., 2017). The first cause of death in Iran is cardiovascular disease, which is responsible for more than

\footnotetext{
* Author for correspondence: Ali Khani Jeihooni, Fasa University of Medical Sciences, Faculty of Health, Department of Public Health, Fasa Ibn Sina Square, 7461686688 Fasa, Iran; e-mail: khani_1512@yahoo.com http://doi.org/10.32725/kont.2019.021 
$46 \%$ of deaths (Fahimfar et al., 2018). Moderating risk factors such as smoking, increased blood pressure, abdominal obesity, psychosocial factors, regular physical inactivity, diabetes, dyslipidemia, alcohol consumption, and reduced consumption of fruits and vegetables play an important role in the emergence of these diseases (Yusuf et al., 2004). Non-moderating risk factors such as age, gender, race, family history, and CVD also play a part (Hinkle and Cheever, 2010). Moderating risk factors are responsible for more than three quarters of ischemic heart disease (WHO, 2009). Indeed, over $90 \%$ of them can be prevented by following a healthy lifestyle (Yusuf et al., 2004). Studies have shown that lifestyle plays a key role in the treatment and prevention of CVD (Ockene and Ockene, 1992; Yusuf et al., 2004). In this regard, educational institutions and programs for raising public awareness are among the key pillars of prevention programs (Werner, 2005). The value of educational programs depends on their effectiveness, which in turn depends largely on the correct use of theories and models in health education (Ghafari et al., 2005). In other words, the selection of a model for education is the first step in the planning process of any health education program; it starts off the proper pattern of the program in the right direction and keeps it in the right direction. The Health Belief Model (HBM) is one of the health education models that is comprehensive and is mainly used to contribute to disease prevention. It is based on individuals' motivation to act and emphasizes how their perceptions motivate and cause behavior in them. The HBM demonstrates the relationship between health beliefs and health behaviors, assuming that preventive behaviors depend on the individual's beliefs (Guvenc et al., 2011; Shojaezadeh, 2000). The results of past studies have shown that HBM can be used as an appropriate model for the prevention of health-related behaviors, including those related to cardiovascular disease (Mehri and Mohaghegh Nejad, 2010; Tavassoli et al., 2010). Based on this model, in order to prevent cardiovascular diseases, people should first be concerned about the problem of developing cardiovascular disease (perceived susceptibility); perceive the depth of this risk and the seriousness of its complications in terms of their physical, social, psychological and economic dimensions (perceived severity); use positive cues from their environment (cues to action); perceive the usefulness and feasibility of CVD prevention (perceived benefits); and deem CVD prevention behaviors as less costly than their benefits (perceived barriers), ultimately leading to cardiovascular prevention behaviors (Heidarnia, 2003; Khosravi et al., 2007).

Baghiani Moghadam et al. (2013), Gautam (2012), Huang et al. (2011), Jones et al. (2006), Katz et al. (2009) and Tol et al. (2012) used the HBM model for CVD prevention.

According to what has been mentioned above, and as cardiovascular disease and its related death toll are prevalent in Fasa city (Fasa Noncommunicable Diseases Research Center, 2015), this study aimed to determine the effect of educational intervention based on the health belief model on the promotion of CVD preventive behaviors among subjects referred to health centers in Fasa city, Fars province, Iran.

\section{Materials and methods}

This study is a quasi-experimental study with 200 subjects (100 experimental group and 100 control group) referred to Fasa health centers in 2017-2018. Two centers were randomly selected from the health centers of Fasa. Subjects were then randomly assigned to two experimental and control groups.
Subjects were selected based on the registered number of their household records in health care centers. The criteria for entering the study included being over the age of 40 years, not being diagnosed with cardiovascular diseases, being physically and mentally able to answer questions, and expressing consent to participation in the study. Exclusion criteria included the reluctance to participate in the study, incomplete response to the questionnaire, and absence in at least two sessions. Data were collected using a questionnaire that was developed based on other studies (Baghiani Moghadam et al., 2013; Gautam, 2012; Huang et al., 2011; Rahimi et al., 2017; Shahabadi, 2009; Tol et al., 2012).

The questionnaire consists of two parts: the first part consists of demographic questions (age, level of education, occupation, history of CVD in the family, history of diabetes, history of hyperlipidemia, history of hypertension, smoking, and body mass index (BMI). The second part of the questionnaire is related to HBM constructs: awareness (20 questions); perceived susceptibility (8 questions) (e.g. "I am at risk of CVD"); perceived severity (8 questions) (e.g. "If I get CVD, I will be hospitalized or will die"); perceived benefits (8 questions) (e.g. "I believe that observing the principles of CVD prevention is effective in protecting people's health"); perceived barriers (8 questions) (e.g. "I cannot afford to buy fruits and vegetables due to their high prices"), perceived self-efficacy (8 questions) (e.g. "I can do physical activity three times a week, each lasting at least 30 minutes"); cues to action (5 questions) (e.g. "Health care workers give me enough information on how to prevent CVD"); and preventive behaviors (15 questions).

In preventive behavior questions, the answer was either yes ( 1 point) or no ( 0 points). To rate questions of awareness, "yes" received 1 point while "no", or "I do not know" received no points. Perceived susceptibility, perceived severity, perceived barriers, perceived benefits, perceived self-efficacy, and cues to action were scored based on the Likert Scale: Strongly disagree (1 point) to Strongly agree (5 points). To assess the validity of the questionnaire, content validation method was used via a panel of experts (which included 10 health education specialists and 2 cardiologists). The content validity ratio was 0.87 and content validity index was 0.88 . To test the reliability, the test re-test method (15 days interval) was used for behavioral and awareness constructs and the Cronbach's alpha coefficient was used for other constructs. The resulting Spearman correlation coefficient was 0.74 for awareness questions and 0.78 for preventive behaviors. The value of Cronbach's alpha coefficient was 0.84 for perceived susceptibility construct, 0.86 for perceived severity, 0.82 for perceived benefits, 0.84 for perceived barriers, 0.81 for perceived self-efficacy, and 0.80 for cues to action.

In the administration phase, after necessary coordination, the researchers attended the health centers. After providing explanations about the research objectives, obtaining informed consent and assuring the confidentiality of the data, the questionnaires were administered to experimental and control groups as the pre-test. Based on the analysis of pre-test results, HBM-based training sessions were designed. Training sessions included 8 sessions held during two months (one session per week) and each session lasted 55-60 minutes. Meetings were held at the Health Center Hall. The time of each session was coordinated by the participants, and they were reminded by telephone to encourage continuous attendance at the sessions. Training methods included: group discussion, film screenings, educational images and posters, question and answer sessions, and practical presentations. The content of the training sessions included the identification of heart dis- 
ease, risk factors, prevention strategies focused on healthy nutrition and weight proportions, appropriate exercises for CVD prevention, and stress management. At the end of the first session, participants were given a booklet and they were asked to study it by the end of the course. In order to increase perceived sensitivity and perceived severity, a CVD patient with conditions similar to that of the target group was asked to attend a training session as a guest and describe the course of his illness to the participants. During the sessions, each participant outlined the barriers to adopting cardiovascular prevention behaviors, and the researchers demonstrated ways to resolve perceived barriers and increase self-efficacy via group discussion and other people's contributions. Since the subjects mentioned health workers and doctors in health care centers as one of the most important ways of collecting information about CVD, experts from health centers, physicians, and some family members were invited to attend a session to discuss access to more detailed information about the services provided in health care centers for CVD patients and their health issues, as well as the time to conduct routine annual tests for those present in the study. At the end of each session, participants were asked to implement the instructions they had received on healthy nutrition, physical activity, and stress management in their daily schedule. At the beginning of each session, subjects who were more successful in this area were introduced and rewarded. The session on healthy nutrition was led by a nutrition expert. At the end of the sessions, a Telegram group was formed for the exchange of information and was used to send a weekly training and motivational message to the Experimental Group. No intervention was performed on the part of the researchers for the control group.

To evaluate the effects of the program, three months after the implementation of the educational interventions, the same questionnaire used in the pretest were administered to the participants of the experimental group and control group. After the post-test, the designed materials were provided to the control group. The study was approved by the Ethics Committee of Fasa University of Medical Sciences, Fasa, Iran (number: 97003, ethical code: IR.FUMS.REC.1397.047).

Data were analyzed by SPSS 22 using Chi-square, independent $t$-test (for comparison between the two groups) and paired $t$-test (for intra-group comparison).

\section{Results}

The age of participants was $50.28 \pm 4.76$ years in the experimental group and $49.85 \pm 4.94$ years in the control group $(p=0.265)$. The mean BMI was $25.13 \pm 2.18$ in the experimental group and $24.86 \pm 2.40(p=0.316)$ in the control group, with no significant difference between the two groups as shown by independent $t$-test. Table 1 shows the frequency distribution of the subjects' demographic characteristics.

Table 1. Frequency distribution of the subjects' demographic characteristics




There was no significant difference between the mean score of awareness in the experimental and the control groups before the intervention, but after the implementation of the educational program, the score of awareness in the experimental group was significantly higher than the control group $(p<0.001)$. The comparison of the two groups in terms of the mean score of perceived susceptibility showed that there was no significant difference between the two groups before the intervention, but there was a significant difference between the experimental group and the control group three months after the intervention $(p<0.001)$. Also, the mean score of perceived severity had no significant difference before the intervention in the two groups, but a significant difference was found in the mean scores between the experimental group and the control group three months after the intervention ( $p<$ 0.001). Perceived benefits scores in two experimental and con- trol groups showed that there was no significant difference in their pre-interventional mean scores, but within 3 months after the intervention, the experimental group's score increased $(p<0.001)$. Comparison of the mean score of perceived barriers in the experimental group and the control group showed that there was no significant difference between the scores of the two groups before the intervention, but after the implementation of the intervention program, the perceived barriers score in the experimental group significantly decreased $(p<0.001)$. Also, after the intervention, the mean score of the self-efficacy construct $(p<0.001)$ and cues to action $(p<0.001)$ was significantly different in the experimental group compared to the control group. Finally, there was a significant increase in the score of preventive behaviors for the participants in the experimental group compared to the control group after the implementation of the educational program, $(p<0.001)$ (Table 2).

Table 2. Comparison of the mean scores of the constructs of the health belief model before and 3 months after the intervention in the experimental and control groups

\begin{tabular}{|c|c|c|c|c|}
\hline Variable & Group & Experimental group & Control group & Independent $t$-test \\
\hline & & mean \pm standard deviation & mean \pm standard deviation & \\
\hline \multirow{4}{*}{ Awareness } & before the intervention & $5.64 \pm 2.25$ & $5.40 \pm 3.72$ & $p=0.275$ \\
\hline & three months after the intervention & $15.16 \pm 2.30$ & $6.09 \pm 2.11$ & $p<0.001$ \\
\hline & difference & $9.52 \pm 2.29$ & $0.69 \pm 3.14$ & \\
\hline & paired $t$-test & $p<0.001$ & $p=0.145$ & \\
\hline \multirow{4}{*}{ Perceived susceptibility } & before the intervention & $16.33 \pm 2.50$ & $16.90 \pm 2.58$ & $p=0.160$ \\
\hline & three months after the intervention & $35.17 \pm 2.84$ & $17.14 \pm 2.60$ & $p<0.001$ \\
\hline & difference & $18.84 \pm 2.62$ & $0.24 \pm 2.57$ & \\
\hline & paired $t$-test & $p<001$ & $p=0.102$ & \\
\hline \multirow{4}{*}{ Perceived severity } & before the intervention & $17.45 \pm 2.80$ & $16.90 \pm 2.86$ & $p=0.114$ \\
\hline & three months after the intervention & $36.14 \pm 2.14$ & $17.17 \pm 2.90$ & $p<0.001$ \\
\hline & difference & $18.69 \pm 2.41$ & $0.27 \pm 2.88$ & \\
\hline & paired $t$-test & $p<0.001$ & $p=0.214$ & \\
\hline \multirow{4}{*}{ Perceived benefits } & before the intervention & $17.61 \pm 2.96$ & $17.81 \pm 2.14$ & $p=0.326$ \\
\hline & three months after the intervention & $35.17 \pm 2.25$ & $18.04 \pm 2.22$ & $p<0.001$ \\
\hline & difference & $17.56 \pm 2.52$ & $0.23 \pm 2.17$ & \\
\hline & paired $t$-test & $p<0.001$ & $p=0.524$ & \\
\hline \multirow{4}{*}{ Perceived barriers } & before the intervention & $32.51 \pm 2.14$ & $23.12 \pm 2.08$ & $p=0.190$ \\
\hline & three months after the intervention & $16.24 \pm 2.80$ & $32.75 \pm 2.10$ & $p<0.001$ \\
\hline & difference & $-16.27 \pm 2.67$ & $9.63 \pm 2.03$ & \\
\hline & paired $t$-test & $p<0.001$ & $p=0.428$ & \\
\hline \multirow{4}{*}{ Perceived self-efficacy } & before the intervention & $15.14 \pm 2.20$ & $16.10 \pm 2.17$ & $p=0.314$ \\
\hline & three months after the intervention & $36.08 \pm 2.41$ & $16.34 \pm 2.26$ & $p<0.001$ \\
\hline & difference & $20.94 \pm 2.29$ & $0.24 \pm 2.22$ & \\
\hline & paired $t$-test & $p<0.001$ & $p=0.335$ & \\
\hline \multirow{4}{*}{ Cues to action } & before the intervention & $8.14 \pm 2.08$ & $8.20 \pm 2.04$ & $p=0.318$ \\
\hline & three months after the intervention & $12.16 \pm 2.25$ & $8.25 \pm 2.10$ & $p<0.001$ \\
\hline & difference & $4.04 \pm 2.15$ & $0.05 \pm 2.60$ & \\
\hline & paired $t$-test & $p<0.001$ & $p=0.170$ & \\
\hline \multirow{4}{*}{ Performance } & before the intervention & $5.14 \pm 1.70$ & $5.09 \pm 1.81$ & $p=0.532$ \\
\hline & three months after the intervention & $12.30 \pm 1.78$ & $5.42 \pm 1.90$ & $p<0.001$ \\
\hline & difference & $7.16 \pm 1.72$ & $0.33 \pm 1.81$ & \\
\hline & paired $t$-test & $p<0.001$ & $p=0.215$ & \\
\hline
\end{tabular}




\section{Discussion}

Cardiovascular diseases are very common and lifestyle plays an important role in their development. Therefore, educational interventions should be conducted using health education theories such as the health belief model to promote preventive behaviors for these diseases (Gautam, 2012). The aim of this study was to determine the effects of an HBM-based educational intervention on the prevention of cardiovascular disease in people over 40 years of age in Fasa city. The results of this study showed that there was no significant difference between the mean scores of awareness in the two experimental and control groups before and after the intervention, but after the implementation of the educational program, the awareness mean score of the participants in the experimental group was significantly higher than that of the control group. A study by Pandey et al. (2013) on 30-70 year-old Indian women showed that educational intervention increased the awareness of the subjects about CVD compared to the pre-intervention stage. The results of a quasi-experimental study by Tavassoli et al. (2010) showed that educational intervention using the Health Belief Model increased the awareness of housewives in Isfahan towards the CVD preventive nutritional behaviors. In a study by Rahimi et al. (2017) on people referred to health centers in Qom, Iran, an educational intervention that included 6 training sessions held for the experimental group increased the subjects' awareness about CVD within 3 months after the intervention. In a study by Harrell et al. (2005), the educational program increased the awareness of the subjects under study on CVD risk factors.

To change behavior, one must be aware of the potential negative consequences of his/her behaviors. Awareness of risk factors helps the individual to make informed decisions about the adoption or continuation of certain behaviors such as smoking, lack of exercise, or consumption of high-fat foods that may increase the risk of CVD (Homko et al., 2008). The findings of this study showed that three months after the intervention, the mean score of perceived susceptibility and perceived severity (perceived threat) increased in the experimental group while there was no significant change in the control group. In a study done by Jones et al. (2006), the perceived susceptibility and perceived severity of the subjects under study regarding CVD were low. In Ali et al. (2002), perceived susceptibility and perceived severity predicted CVD preventive behaviors in the women in the study. In the study of Baghianimoghadam et al. (2013), carried out with the aim of promoting self-care behaviors in patients with heart failure, educational intervention increased the mean score of perceived susceptibility and perceived severity in the experimental group. In the study by Sharifi et al. (2016) on self-care behaviors in hypertensive patients using the Health Belief Model, the experimental group received an educational intervention for 8 sessions. Three months after the intervention, the experimental group's mean score of perceived susceptibility and perceived severity increased significantly.

The results of the Ammouri et al. (2011) study showed that most of the women surveyed did not consider themselves vulnerable to CVD and needed intervention to increase it. People with low perceived susceptibility regarding the risks of CVD tend to have lower adherence to healthy dietary behaviors. This low perception negatively influences the cost-benefit evaluation of adopting a behavior and the resulting decisions (Rahimi et al., 2017). The results of Rahmati-Najarkolaei et al. (2015) also showed that perceived severity affected physical activity about cardiovascular disease more than any other factor. Therefore, identifying the perceived severity of a disease and its enhancement by expressing negative outcomes associated with the disease will be helpful in improving preventive behaviors. In this study, the experimental group's mean score on perceived benefits increased in three months after the intervention, and the mean score of perceived barriers decreased, while there was no significant change in the control group. Perceived benefits and barriers are among the strongest predictors of behavior, especially when the purpose of the recommended behavior is to prevent a negative health outcome versus the treatment of an existing health condition (Carpenter, 2010). Lifestyle interventions such as increasing physical activity and reducing the daily intake of fat and stress management have had benefits for the prevention of CVD and the health of individuals. These include improved health, better feelings, longer lives, and reduced medical drug intake (Bhupathiraju and Tucker, 2011; Mosca et al., 2006). The results of the study conducted by Chatripour et al. (2016) showed that the educational intervention based on HBM increased the mean score of perceived benefits for the prevention of CVD among teachers, while other constructs of the HBM did not change. Shojaei et al. (2016) used HBM for Coronary Artery Bypass Graft (CABG) patients and found that educational intervention increased perceived barriers and benefits in the experimental group. The results of the Walker et al. (2006) study on rural women showed that increased perceived benefits and decreased perceived barriers of healthy nutrition behaviors and physical activity contributed to the promotion of healthy lifestyle. Benefits such as improving the cardiovascular system, increasing fitness, and reducing the risk of coronary heart diseases are some of the perceived benefits mentioned by middle-aged women in this study. The fatigue and timing of exercises, and the limitations and tastelessness of healthy meals were among the barriers to physical activity and healthy eating mentioned by these women. Theory-based educational interventions help health trainers to identify and provide solutions to barriers that discourage people from doing activities that upgrade their health and CVD preventive behaviors (Fung et al., 2018). Individuals' beliefs that they are able to properly manage CVD-related health behaviors can be effective in promoting self-efficacy among people in the community, and people who believe they have higher ability and confidence to conduct healthy behaviors, are more likely to adopt them (Sol et al., 2011). The results of this study indicated an increase in the mean score of self-efficacy of individuals three months after the intervention in the experimental group. The results of the study by Yehle and Plake (2010) showed that educational interventions could increase self-efficacy in patients with heart failure. The results of Huang et al. (2011), Rahimi et al. (2017) and Zeinali et al. (2015) showed that educational intervention significantly increased the self-efficacy scores of the experimental group. To increase self-efficacy, it is recommended to use techniques such as focussing on practical achievements, rewards, role modeling and substitute experiences. Setting short-term and achievable goals will increase self-confidence in one's abilities (Napolitano et al., 2008; Pozehl et al., 2010). Cues to action here refer to perceived social pressure and internal stimuli (external and internal cues to action) that can lead people to adopt CVD preventive behaviors (Shojaei et al., 2016). In this study, the mean score of cues to action in the experimental group was significantly higher than that of the control group three months after the intervention. Cues to action in this study were mostly family members, doctors, and staff at health centers, who had an essential role as sources 
of information and support for people to perform CVD preventive behaviors. In the study of Mehri et al. (2010), family was the most important source of information for people with CVD. In studies by Rahimi et al. (2017), Zeinali et al. (2015), Khani Jeihooni et al. (2017), and Kashfi et al. (2012), educational intervention increased the mean scores of cues to action in the experimental group. In this study, the mean score of CVD preventive behaviors (performance) did not show any significant difference between the two groups before intervention, but there was a significant increase in the experimental group's score three months after the intervention. The results of Rahimi et al. (2017), Baghianimoghaddam et al. (2013), Zeinali et al. (2015), Tavassoli et al. (2010), Al-Ali and Haddad (2004) and Shojaei et al. (2016) are consistent with this study in this regard. Lifestyle interventions can be effective in improving behavior. Also, interventions that improve an individual's ability to identify barriers to behavior change and identify potential problems and solutions are more successful both in achieving objectives and maintaining them (Franklin and Cushman, 2011).

Carrying out a community-based educational intervention for people over the age of 40 , who are at risk of cardiovascular disease, was one of the benefits of this study. One of the limitations of this study was the self-reporting of the individuals' performance in preventing cardiovascular disease.

\section{Conclusions}

The results of this study showed the effectiveness of the intervention program and the need to use educational interven- tions designed to improve the adoption of CVD preventive behaviors. HBM-based education increased the mean scores of awareness and HBM constructs in the experimental group and caused them to better perform CVD prevention activities. Preventive interventions should be designed according to the needs and characteristics of the target population in order to prevent the risk of cardiovascular disease. Considering the sensitivity and vulnerability of people over the age of 40 years and the role of social supporters, the need to provide a fundamental solution and proper planning for the prevention of cardiovascular diseases with regard to reducing unhealthy lifestyle is quite tangible. It is essential to provide training programs especially for family members, doctors and other health personnel, as well as through the mass media - especially audio-visual ones.

\section{Conflict of interests}

The authors declare no conflict of interests regarding this article.

\section{Acknowledgements}

This study is part of an MD thesis (code 97003) sponsored by the Fasa University of Medical Sciences. Our warm thanks go to the Research and Technology Dept. of Fasa University of Medical Sciences, as well as those referred to the health centers of Fasa, for their participation in the study.

\section{Vliv vzdělávací intervence založené na modelu zdravotního přesvědčení, na zlepšení preventivního chování, které má vliv na kardiovaskulární onemocnění, u subjektů ve zdravotnickém středisku v íránském městě Fasa}

\section{Souhrn}

Cíl: Kardiovaskulární onemocnění patří v mnoha zemích k těm nepřenosným nemocem, které jsou jednou z hlavních příčin úmrtí a pro společnost představují velkou zdravotní, sociální a ekonomickou zátěž. Cílem této studie bylo zjistit vliv vzdělávací intervence založené na modelu zdravotního přesvědčení, na zlepšení preventivního chování, které má vliv na kardiovaskulární onemocnění, u subjektů ve zdravotnickém středisku v íránském městě Fasa v provincii Fars.

Metody: Jedná se o kvaziexperimentální studii zahrnující 200 subjektů (skupinu 100 experimentálních subjektů a skupinu 100 kontrolních subjektů), které pobývaly ve zdravotnických střediscích ve městě Fasa v letech 2017-2018. Data byla shromážděna pomocí dotazníku, do kterého byly zahrnuty demografické proměnné, povědomí, model zdravotního přesvědčení a preventivní chování. Dotazníky byly vyplněny oběma skupinami před intervencí a následně 3 měsíce po intervenci. Semináře zahrnovaly 8 setkání, která se konala v průběhu 2 měsíců (1 setkání týdně), přičemž každé setkání trvalo 55-60 minut. Data byla následně vložena do SPSS 19 a analyzována chí-kvadrátovým testem, nezávislým t-testem a deskriptivními statistickými metodami. $P<0,05$ bylo považováno za statisticky významné.

Výsledky: Věk subjektů v experimentální skupině byl 50,28 $\pm 4,76$ let, v kontrolní skupině 49,85 $\pm 4,94$ let $(p=0,265)$. Průměrný BMI v experimentální skupině byl $25,13 \pm 2,18$ a v kontrolní skupině $2,40(p=0,316)$. Průměrné skóre vyplývající z modelu zdravotního přesvědčení bylo v experimentální skupině ve srovnání se skóre po intervenci výrazně vyšší $(P<0,05)$.

Závěr: Výsledky prokázaly efektivitu intervenčního programu a potřebu vzdělávacích programů vytvořených pro lepší osvojení si preventivního chování, které má vliv na kardiovaskulární onemocnění.

Klíčová slova: kardiovaskulární onemocnění; model zdravotního přesvědčení; vzdělávací intervence 


\section{References}

1. Al-Ali N, Haddad LG (2004). The effect of the health belief model in explaining exercise participation among Jordanian myocardial infarction patients. J Transcult Nurs 15(2): 114-210. DOI: 10.1177/1043659603262484.

2. Ali NS (2002). Prediction of coronary heart disease preventive behaviors in women: a test of the health belief model. Women Health 35(1): 83-96. DOI: 10.1300/J013v35n01_06.

3. Ammouri AA, Neuberger G, Mrayyan MT, Hamaideh SH (2011) Perception of risk of coronary heart disease among Jordanians. J Clin Nurs 20(1-2): 197-203. DOI: 10.1111/j.13652702.2010.03192.x.

4. Baghiani Moghadam MH, Mirzaei M, Rahimdel T (2013). Role of health beliefs in preventive behaviors of individuals at risk of cardiovascular diseases. J Health Syst Res 8(7): 1151-1158.

5. Baghianimoghadam MH, Shogafard G, Sanati HR, Baghianimoghadam B, Mazloomy S, Askarshahi M (2013). Application of the health belief model in promotion of self-care in heart failure patients. Acta Med Iran 51(1): 52-58.

6. Bhupathiraju SN, Tucker KL (2011). Coronary heart disease prevention: Nutrients, foods, and dietary patterns. Clin Chim Acta 412(17-18): 1493-1514. DOI: 10.1016/j.cca.2011.04.038.

7. Carpenter CJ (2010). A meta-analysis of the effectiveness of health belief model variables in predicting behavior. Health Commun 25(8): 661-669. DOI: 10.1080/10410236.2010.521906.

8. Chatripour R, Shojaeizade D, Tol A, Sayehmiri K, Asfeia A, Kia F (2016). The impact of teacher education on promoting knowledge, attitude and performance of students in prevention of cardiovascular diseases: Application of the HBM model. Razi Medical Journal 23(146): 26-35.

9. Fahimfar N, Khalili D, Sepanlou SG, Malekzadeh R, Azizi F, Mansournia MA, et al. (2018). Cardiovascular mortality in a Western Asian country: results from the Iran Cohort Consortium. BMJ Open 8(7): e020303. DOI: 10.1136/ bmjopen-2017-020303.

10. Fasa Noncommunicable Diseases Research Center (2015). Fasa Cohort study. [online] [cit. 2018-03-25]. Available from: https:// ncdrc.fums.ac.ir/activities/cohort-studies/adult-cohort

11. Franklin BA, Cushman M (2011). Recent advances in preventive cardiology and lifestyle medicine. Circulation 123(20): 22742283. DOI: $10.1161 /$ CIRCULATIONAHA.110.981613.

12. Fung V, Graetz I, Reed M, Jaffe MG (2018). Patient-reported adherence to statin therapy, barriers to adherence, and perceptions of cardiovascular risk. PLoS One 13(2): e0191817. DOI: 10.1371/journal.pone.0191817.

13. Gautam YR (2012). A study of assessing knowledge and health beliefs about cardiovascular disease among selected undergraduate university students using Health Belief Model. Southern Illinois University Carbondale.

14. Gaziano TA, Bitton A, Anand S, Gessel SA, Murphy A (2010). Growing epidemic of coronary heart disease in low-and middle-income countries. Curr Probl Cardiol 35(2): 72-115. DOI: 10.1016/j.cpcardiol.2009.10.002.

15. GBD 2016 Causes of Death Collaborators (2017). Global, regional, and national age-sex specific mortality for 264 causes of death, 1980-2016: a systematic analysis for the Global Burden of Disease Study 2016. Lancet 390(10100): 1151-1210. DOI: 10.1016/S0140-6736(17)32152-9.

16. GBD 2016 Disease and Injury Incidence and Prevalence Collaborators (2017). Global, regional, and national incidence, prevalence, and years lived with disability for 328 diseases and injuries for 195 countries, 1990-2016: a systematic analysis for the Global Burden of Disease Study 2016. Lancet 390(10100): 1211-1259. DOI: 10.1016/S0140-6736(17)32154-2.

17. Ghafari M, Niknami SH, Kasemnejad A (2005). Design and validity HIV/AIDS Questionnaire in Teen Kermanshah. Kermanshah Journal of university medical sciences services 11(1): 33-42.

18. Guvenc G, Akyuz A, Açikel CH (2011). Health Belief Model Scale for Cervical Cancer and Pap Smear Test: Psychometric
Testing. J Adv Nurs 67(2): 428-437. DOI: 10.1111/j.13652648.2010.05450.x.

19. Harrell TK, Davy BM, Stewart JL, King DS (2005). Effectiveness of a school-based intervention to increase health knowledge of cardiovascular disease risk factors among rural Mississippi middle school children. South Med J 98(12): 1173-1180. DOI: 10.1097/01.smj.0000182499.59715.07.

20. Heidarnia AR (2003). Discussion in health education process. Tehran: Zamani Publication, pp. 91-94.

21. Heidenreich PA, Trogdon JG, Khavjou OA, Butler J, Dracup K, Ezekowitz MD, et al. (2011). Forecasting the future of cardiovascular disease in the United States: a policy statement from the American heart association. Circulation 123(8): 933-944. DOI: 10.1161/CIR.0b013e31820a55f5.

22. Hinkle JL, Cheever KH (2010). Brunner \& Suddarth's textbook of medical-surgical nursing. Iran: Hakim Publication.

23. Homko CJ, Santamore WP, Zamora L, Shirk G, Gaughan J, Cross R, et al. (2008). Cardiovascular disease knowledge and risk perception among underserved individuals at increased risk of cardiovascular disease. J Cardiovasc Nurs 23(4): 332-337. DOI: 10.1097/01.JCN.0000317432.44586.aa.

24. Hosseini-Esfahani F, Mousavi Nasl Khameneh A, Mirmiran P, Ghanbarian A, Azizi F (2011). Trends in risk factors for cardiovascular disease among Iranian adolescents: the Tehran lipid and glucose study, 1999-2008. J Epidemiol 21(5): 319-328. DOI: 10.2188/jea.JE20100162.

25. Huang MSL, Kandiah M, Yassin Z, Abedi P (2011). Lifestyle change using the health belief model to improve cardiovascular risk factors among postmenopausal women. Sci Res J Health Sys Res 7(1): 127-137.

26. Institute for Health Metrics and Evaluation (2018). Global burden of diseases 2016. University of Washington. [online] [cit. 2018-03-25]. Available from: https://vizhub.healthdata. org/gbd-compare/

27. Jones DE, Weaver MT, Grimley D, Appel SJ, Ard J (2006). Health belief model perceptions, knowledge of heart disease, and its risk factors in educated African-American women: an exploration of the relationships of socioeconomic status and age. J Natl Black Nurses Assoc 17(2): 13-23.

28. Kashfi SM, Khani Jeihooni A, Rezaeianzade A (2012). Effect of health workers' training programs on preventive behavior of leishmaniosis based on BASNEF model. J Res Health Sci 12(2): 114-118.

29. Katz DA, Graber M, Birrer E, Lounsbury P, Baldwin A, Hillis SL, Christensen AJ (2009). Health beliefs toward cardiovascular risk reduction in patients admitted to chest pain observation units. Acad Emerg Med 16(5): 379-387. DOI: 10.1111/j.15532712.2009.00383.x. Epub 2009 Mar 16.

30. Khani Jeihooni A, Askari A, Kashfi SM, Khiyali Z, Kashfi SH, Safari O, et al. (2017). Application of health belief model in prevention of osteoporosis among primary school girl students. Int J Pediatr 5(11): 6017-6029. DOI:10.22038/ ijp.2017.25144.2130.

31. Khosravi Sh, Jahani F, Gazerani N, Eshrati B, Moghimi M (2007). Determining knowledge and attitude of students in Arak University of medical sciences about Ecstasy based on Health Belief Model in 2006. Rahavard Danesh Journal 10(2): 15-21.

32. Mathers CD, Loncar D (2006). Projection of global mortality and burden of disease from 2002 to 2030. PLos Med 3(11): e442. DOI: 10.1371/journal.pmed.0030442.

33. Mehri A, Mohaghegh Nejad MR (2010). Utilizing the health belief model to predict preventive behaviors for heart diseases in the students of Islamic Azad University of Sabzevar. Tolooe Behdasht 9(29): 21-32.

34. Moran A, Gu D, Zhao D, Coxson P, Wang YC, Chen CS, et al. (2010). Future cardiovascular disease in China: Markov model and risk factor scenario projections from the coronary heart disease policy model China. Circ Cardiovasc Qual Outcomes 3(3): 243-252. DOI: 10.1161/CIRCOUTCOMES.109.910711.

35. Mosca L, Mochari H, Christian A, Berra K, Taubert K, Mills T, et al. (2006) National study of women's awareness, preventive action, and barriers to cardiovascular health. Circulation 113(4): 525-534. DOI: 10.1161/CIRCULATIONAHA.105.588103. 
36. Murray CJL, Alan D, Lopez AD (1996). The global burden of disease: a comprehensive assessment of mortality and disability from diseases injuries and risk factors in 1990 and projected to 2020. Cambridge: Harvard University Press.

37. Napolitano MA, Papandonatos GD, Lewis BA, Whiteley JA, Williams DM, King AC, et al. (2008). Mediators of physical activity behavior change: A multivariate approach. Health Psychol 27(4): 409-418. DOI: 10.1037/0278-6133.27.4.409.

38. Ockene IS, Ockene JK (1992). Prevention of coronary heart disease. Boston: Little Brown \& Co.

39. Pandey RM, Agrawal A, Misra A, Vikram NK, Misra P, Dey S et al. (2013). Population-based intervention for cardiovascular diseases related knowledge and behaviours in Asian Indian women. Indian Heart J 65(1): 40-47. DOI: 10.1016/j. ihj.2012.12.019.

40. Peykari N, Hashemi H, Dinarvand R, Haji-Aghajani M, Malekzadeh R, Sadrolsadat A, et al. (2017). National action plan for non-communicable diseases prevention and control in Iran; a response to emerging epidemic. J Diabetes Metab Disord 16(1): 3. DOI: 10.1186/s40200-017-0288-4.

41. Pozehl B, Duncan K, Hertzog M, Norman JF (2010). Heart failure exercise and training camp: Effects of a multicomponent exercise training intervention in patients with heart failure. Heart Lung 39(6 Suppl): S1-13. DOI: 10.1016/j. hrtlng.2010.04.008.

42. Rahimi T, Shojaei S, Mousavi Miyandashti Z, Amini Z, Khazir Z (2017). Promotion of preventive behaviors of cardiovascular diseases using health belief model in women referring to health centers in Qom, Iran. Qom Univ Med Sci J 10(12): 44-53.

43. Rahmati-Najarkolaei F, Tavafian SS, Gholami Fesharaki M, Jafari MR (2015). Factors predicting nutrition and physical activity behaviors due to cardiovascular disease in Tehran university students: Application of health belief model. Iran Red Crescent Med J 17(3): e18879. DOI: 10.5812/ircmj.18879.

44. Shahabadi S (2009). The effect education based on health belief model on knowledge and attitude about in the heartcardiovascular disease in health centers staff Kermanshah province. TUMS 111.

45. Sharifi A, Jeihooni A K, Vahdat S (2016). The study of impact the training program on behavior self-regulating blood pressure in patients of hypertension in Shiraz, based on Health Belief Model in 2016. IJARSET 3(7): 55-60.

46. Shojaei S, Farhadloo R, Aein A, Vahedian M (2016). Effects of the health belief model (HBM)-based educational program on the nutritional knowledge and behaviors of $C A B G$ patients. J Teh Univ Heart Ctr 11(4): 181-186.
47. Shojaezadeh D (2000). Health Education Models. Tehran Communication and health education centre, Ministry of Health and Medical Education, pp. 29-30.

48. Sol BG, van der Graaf Y, van Petersen R, Visseren FL (2011). The effect of self-efficacy on cardiovascular lifestyle. Eur J Cardiovasc Nurs 10(3): 180-186. DOI: 10.1016/j ejcnurse.2010.06.005. Epub 2010 Jul 31.

49. Tavassoli E, Hasanzadeh A, Ghiasvand R, Tol A, Shojaezadeh D (2010). Effect of health education based on the Health Belief Model on improving nutritional behavior aiming at preventing cardiovascular disease among housewives in Isfahan. Journal of School of Public Health and Institute of Public Health Research 8(3): 11-24.

50. Tol A, Esmaeili Shahmirzadi S, Shojaeizadeh D, Eshraghian MR, Mohebbi B (2012). Determination of perceived barriers and benefits of adopting health-promoting behaviors in cardiovascular diseasesprevention: application of preventative behavior model. Payavarde Salamat Journal 6(3): 204-214.

51. Walker SN, Pullen CH, Hertzog M, Boeckner L, Hageman PA (2006). Determinants of older rural women's activity and eating. West J Nurs Res 28(4): 449-468. DOI: $10.1177 / 0193945906286613$.

52. Werner P (2005). Knowledge about osteoporosis: assessment, correlate and outcomes. Osteoporosis Int 16(2): 115-127. DOI: 10.1007/s00198-004-1750-y.

53. WHO (2009). Global Health Risks. Mortality and burden of disease attributable to selected major risks [online] [cit. 201112-05]. Available from: https://www.who.int/healthinfo/global burden_disease/GlobalHealthRisks_report_full.pdf

54. Yehle KS, Plake KS (2010). Self-efficacy and educational interventions in heart failure: A review of the literature. J Cardiovasc Nurs 25(3): 175-188. DOI: 10.1097/ JCN.0b013e3181c71e8e.

55. Yusuf S, Hawken S, Ounpuu S, Dans T, Avezum A, Lanas F, et al. (2004). Effect of potentially modifiable risk factors associated with myocardial infarction in 52 countries (the interheart study): case-control study. Lancet 364(9438): 937-952. DOI: 10.1016/S0140-6736(04)17018-9.

56. Zeinali M, Asadpour M, Aghamolaei T, Nadimi E, Farshidi H, Ghanbarnejad A (2015). The effect of educational intervention based on health belief model on behavioral promotion preventing cardiovascular disease in people with natural angiography. J Prev Med 1(2): 1-12. 